Boston University School of Law

Scholarly Commons at Boston University School of Law

Faculty Scholarship

$5-2020$

\title{
Mr. Gorsuch, Meet Mr. Marshall: A Private-Law Framework for the Public-Law Puzzle of Subdelegation
}

Gary S. Lawson

Boston Univeristy School of Law

Follow this and additional works at: https://scholarship.law.bu.edu/faculty_scholarship

Part of the Supreme Court of the United States Commons

\section{Recommended Citation}

Gary S. Lawson, Mr. Gorsuch, Meet Mr. Marshall: A Private-Law Framework for the Public-Law Puzzle of Subdelegation, in No. 20-16 Boston University School of Law Public Law \& Legal Theory Paper (2020). Available at: https://scholarship.law.bu.edu/faculty_scholarship/909

This Working Paper is brought to you for free and open access by Scholarly Commons at Boston University School of Law. It has been accepted for inclusion in Faculty Scholarship by an authorized administrator of Scholarly Commons at Boston University School of Law. For more information, please contact lawlessa@bu.edu. 


\title{
BU School of Law
}

\section{Mr. Gorsuch, MeEt Mr. MARShall: A PRIVATE-LAW FRAMEWORK FOR THE Public-Law Puzzle of Subdelegation}

\author{
Boston University School of Law \\ Public Law \& Legal Theory Paper No. 20-16
}

May 2020

Gary Lawson

Boston University School of Law

Forthcoming, American Enterprise Institute 
Mr. Gorsuch, Meet Mr. Marshall: A Private-Law Framework for the Public-Law Puzzle of
Subdelegation

Gary Lawson*

(forthcoming, American Enterprise Institute)

\begin{abstract}
In the wake of Gundy v. United States, 139 S.Ct. 2116 (2019), there is reason to think that five Justices might be willing to consider reviving the constitutional non-subdelegation doctrine. But in what form? Judges and scholars have labored for more than two centuries to come up with a legally rigorous standard for evaluating the permissible scope and breadth of congressional grants of discretion to executive and judicial agents. Some, such as Justice Scalia, eventually gave up in despair. That is a grave mistake. Lawyers had faced subdelegation questions for centuries before the Constitution was ratified, in the context of private-law agency arrangements. There are good reasons to think that the Constitution draws on private-law background norms for much of its meaning, and the subdelegation problem is an excellent candidate for elaboration in privatelaw terms. Thus, when Chief Justice John Marshall in 1825 drew a distinction between impermissible grants of discretion on "important subjects" and permissible grants of discretion on matters of "less interest," his approach was far more structured, grounded in precedent, and law-like than may appear at first glance. It drew on principles and case law developed in settings ranging from powers of appointment in wills, in which the holder of the power tries to designate another person to exercise it, to the lack of privity between merchants and subdelegees in the absence of express authority on the part of the agents to subdelegate power, to the lack of authority of factors and supercargoes to entrust sale of goods to subagents without the express consent of their principals. Thus, judges worried about the open-ended character of a non-subdelegation doctrine need not run away from Chief Justice Marshall's classic formulation. They simply need to flesh out its private-law background. There was abundant law regarding subdelegation in the eighteenth and nineteenth centuries, and the Constitution's subdelegation principle is grounded in that law.
\end{abstract}

In 1825, Chief Justice John Marshall confidently proclaimed that "[i]t will not be contended that Congress can delegate to the Courts, or to any other tribunal, powers which are strictly and exclusively legislative." ${ }^{1}$ He explained that "[t]he difference between the departments

\footnotetext{
* Philip S. Beck Professor, Boston University School of Law. I am profoundly grateful to Peter Wallison for making so many insightful suggestions and comments that he should probably be listed as a co-author. I thank Robert G. Natelson for making it all possible and Guy Seidman for helping make the possible a reality. And I am grateful to Philip S. Beck and Boston University School of Law for unfailing support of scholarship.

1 Wayman v. Southard, 23 U.S. (10 Wheat.) 1, 42 (1825). In contemplating what will and will not be contended, Chief Justice Marshall evidently anticipated neither the modern legal academy, see Julian Davis Mortenson \& Nicholas Bagley, Delegation at the Founding, -- CoLuM. L. ReV.-(----); Eric A. Posner \& Adrian Vermeule, Interring
} 
undoubtedly is, that the legislature makes, the executive executes, and the judiciary construes the law."2 One might term this the "civics book” model of government: each federal institution has its constitutionally assigned role; and the assigned role of the legislature is to make the law, which the other departments will then execute and/or interpret.

The problem with the civics book model, even on its own terms, is that it assumes that one can readily distinguish the making of a law from its execution or interpretation. Sometimes that distinction seems straightforward. If Congress enacted into the United States Code a literal inkblot, ${ }^{3}$ surely it would functionally, and constitutionally, be an act of lawmaking rather than execution or interpretation for the executive or judiciary to purport to apply that content-less “law." (For someone who doubts the existence of any kind of constitutional subdelegation ${ }^{4}$ rule, this example is a good test case.) But at other times the lines among those government functions and departments become downright Robin-Thicke-like blurry. If the executive “executes” and the

the Nondelegation Doctrine, 69 U. CHI. L. REv. 1721 (2002), nor modern Supreme Court Justices. See Whitman v. American Trucking Ass'ns, 531 U.S. 457, 487 (2001) (Stevens, J., concurring in part and concurring in the judgment). In defense of Chief Justice Marshall: How could anyone in 1825 - outside of an asylum -- anticipate the modern legal academy or modern Supreme Court Justices?

223 U.S. (10 Wheat) at 42.

3 Cf. Robert H. Bork, the Tempting of America: The Political Seduction of the LAW 166 (1990) (calling the Fourteenth Amendment's Privileges or Immunities Clause an "indecipherable inkblot").

4 It is conventional in constitutional discourse to refer to "nondelegation" or the "nondelegation doctrine" when discussing the ability of Congress to vest discretion in executive or judicial officials. For reasons explained here and elsewhere, see infra --, the proper terms are "subdelegation" and the "non-subdelegation doctrine." Power is initially delegated by the people, through the vehicle of the Constitution, to Congress, and the question is whether Congress, pursuant to the instrument of delegation, can then subdelegate all or part of its delegated authority to some other actor. See Philip Hamburger, Is Administrative Law Unlawful? 377 (2014). Accordingly, while the term "nonsubdelegation doctrine" is concededly a bit awkward, this is an instance in which intellectual precision is more important than elegance, and I will accordingly use the terms "subdelegation" and "non-subdelegation doctrine" rather than their more familiar but less accurate substitutes. 
judiciary “construes” the Clean Air Act ${ }^{5}$ or Section 10(b) of the Securities Exchange Act, ${ }^{6}$ are they in truth performing a legislative function? Do those statutes, and countless others like them, subdelegate to other actors "powers which are strictly and exclusively legislative" and hence are not subdelegable?

Chief Justice Marshall two centuries ago was acutely aware of this potential line-drawing problem. Right after laying out the civics-book model, he added, "but the maker of the law may commit something to the discretion of the other departments, and the precise boundary of this power is a subject of delicate and difficult inquiry."7 That sounds ominous to persons who worry about constraints on judges. ${ }^{8}$ How would one conduct such a "delicate and difficult inquiry" in order to determine when and whether congressional grants of discretion to other actors cross a constitutional line? How could that possibly serve as a judicially administrable test for ascertaining the limits of congressional grants of discretion?

5 See 42 U.S.C. § 7409(b)(1) (2018) (defining primary air quality standards, to be set by the Administrator of the Environmental Protection Agency, as "ambient air quality standards the attainment and maintenance of which in the judgment of the Administrator, based on such criteria and allowing an adequate margin of safety, are requisite to protect the public health").

6 See 15 U.S.C. § 78j(b) (2018) (declaring it unlawful "to use or employ, in connection with the purchase or sale of any security ... any manipulative or deceptive device or contrivance in contravention of such rules and regulations as the Commission may prescribe as necessary or appropriate in the public interest or for the protection of investors").

7 Wayman, 23 U.S (10 Wheat.) at 42-43. Accord: The Federalist No. 37 (1788) (James Madison) (“Experience has instructed us that no skill in the science of government has yet been able to discriminate and define, with sufficient certainty, its three great provinces - the legislative, executive, and judiciary .... Questions daily occur in the course of practice which prove the obscurity which reigns in these subjects, and which puzzle the greatest adepts in political science.”).

8 For myself, I worry much less about constraints on judges than I do about getting constitutional meaning right, especially when one is talking about something as basic to the Constitution as its allocation of powers among different institutions. But that is a topic for another day. See, e.g., Steven G. Calabresi \& Gary Lawson, The Rule of Law as a Law of Law, 90 Notre DAME L. REV. 483 (2014). The point of this contribution is to show that, whatever may be true in other contexts, the constitutional rule against subdelegation is both interpretatively correct and consistent with judicial modesty, to the extent that one considers judicial modesty an important value. 
Chief Justice Marshall had an answer: "The line has not been exactly drawn which separates those important subjects, which must be entirely regulated by the legislature itself, from those of less interest, in which a general provision may be made, and power given to those who are to act under such general provisions to fill up the details ....”9

That's it? That's all that America's most famous Chief Justice could come up with? It's okay for executives and courts to handle matters of "less interest," but Congress has to decide on the “important subjects”?

Yes, actually, that's it. That is the best that John Marshall could do in 1825. It is also the best that I could do in 1994 when I first tried to formulate an originalist account of the Constitution's non-subdelegation principle and came up with: "Congress must make whatever policy decisions are sufficiently important to the statutory scheme at issue so that Congress must make them.” 10 Eight years later, I still could do no better:

Chief Justice Marshall’s circular formulation was right all along, and rather than wind our way back to it indirectly, we might as well take the freeway. The line between legislative and executive power (or between legislative and judicial power) must be drawn in the context of each particular statutory scheme. In every case, Congress must make the central, fundamental decisions, but Congress can leave ancillary matters to the President or the courts. One can try to find alternative ways to express the distinction between fundamental and ancillary matters, such as focusing on case-resolving power or demonstration of political commitment or choices among salient alternatives, but in the end, one cannot really get behind or beneath the fact that law execution and application

9 Wayman, 23 U.S. (10 Wheat.) at 43 (emphasis added).

10 Gary Lawson, The Rise and Rise of the Administrative State, 107 HARV. L. REV. 1231, 1239 (1994). 
involve discretion in matters of "less interest" but turn into legislation when that

discretion extends to "important subjects." That is the line that the Constitution draws,

and there is no escape from it. ${ }^{11}$

The seeming vagueness of these Marshallian/Lawsonian formulations is surely what gives pause to some judges, including most notably the irreplaceable Justice Scalia, ${ }^{12}$ about whether a constitutional non-subdelegation doctrine is judicially manageable.

There is some reason to think that Justice Neil Gorsuch shares these concerns - not enough to abandon the non-subdelegation principle altogether but enough to lead him to search for an alternative account of the principle. In Gundy v. United States, ${ }^{13}$ Justice Gorsuch called for resurrection of the non-subdelegation doctrine after more than eighty years of dormancy. ${ }^{14}$ He managed to get not only Justice Thomas but also Chief Justice Roberts to join his opinion, and Justice Alito indicated that he would be willing to reconsider the Court's subdelegation jurisprudence if four other votes can be found. ${ }^{15}$ Shortly thereafter, Justice Kavanagh, who did

11 Gary Lawson, Delegation and Original Meaning, 88 VA. L. REV. 327, 376-77 (2002).

12 Although Professor Antonin Scalia was quite keen on resurrecting the non-subdelegation doctrine, see Antonin Scalia, A Note on the Benzene Case, RegulAtion, July/Aug. 1980, at 25, 28 ("even with all its Frankenstein-like warts, knobs, and (concededly) dangers, the unconstitutional delegation doctrine is worth hewing from the ice.”), Justice Antonin Scalia became perhaps the Court's most forceful opponent of policing the breadth of Congress's grants of discretion to executive or judicial agents. See Whitman v. American Trucking Ass'ns, 531 U.S. 457 (2001); Mistretta v. United States, 488 U.S. 361, 415-16 (Scalia, J., dissenting). His reasons for declaring the nonsubdelegation doctrine effectively unenforceable were grounded in judicial restraint rather than constitutional meaning: "Once it is conceded, as it must be, that no statute can be entirely precise, and that some judgments, even some judgments involving policy considerations, must be left to the officers executing the law and the judges applying it, the debate over unconstitutional delegation becomes a debate not over a point of principle but over a question of degree." Id. For Justice Scalia, anything that was a matter of degree rather than principle was prima facie nonjusticiable. See Calabresi \& Lawson, supra note 4 (critically examining Justice Scalia's commitment to rules in constitutional adjudication).

13139 S.Ct. 2116 (2019).

14 See id. at 2131 (Gorsuch, J., dissenting).

15 See id. at 2130) (Alito, J., concurring in the judgment). 
not participate in Gundy, wrote in a concurrence to a denial of certiorari that “JUSTICE GORSUCH's thoughtful Gundy opinion raised important points that may warrant further consideration in future cases." 16 That sounds a lot like five Justices at least willing to think carefully about reviving some kind of non-subdelegation doctrine. The question is: What kind of doctrine are they prepared to revive? Would five Justices today be willing to agree with Chief Justice Marshall that courts need to distinguish "important subjects" from "matters of less interest”?

It is evident that Justice Gorsuch had these concerns much on his mind in Gundy. It is a mortal certainty that Justice Gorsuch is well aware both of Chief Justice Marshall's account of subdelegation and of my belief that Chief Justice Marshall was essentially right as a matter of original meaning; Justice Gorsuch’s dissenting opinion in Gundy cites - on more than one occasion -- both Wayman v. Southard ${ }^{17}$ and me. ${ }^{18}$ But those multiple citations conspicuously avoid emphasizing the test for subdelegations that Chief Justice Marshall and I endorsed. ${ }^{19}$ Justice Gorsuch had something else to offer in response to his own question: "What's the test?”20

After noting Marshall’s and Madison's observations about the difficulty of the inquiry, Justice Gorsuch found three principles that he believes can and should guide an inquiry into the boundaries of the legislative power to vest discretion in executive or judicial actors:

16 Paul v. United States, 589 U.S. - (2019 (statement of Justice Kavanagh respecting the denial of certiorari).

17 See 139 S.Ct. at 2133, 2135, 2137 (Gorsuch, J, dissenting).

18 See id. at 2135, 2140 (Gorsuch, J., dissenting).

19 Chief Justice Marshall's formulation gets cited at one point, see id. at 2136 (Gorsuch, J., dissenting), but, as we will shortly see, the test gets reframed by Justice Gorsuch to mean something very different from what it actually says. See infra --. My proposed formulation, understandably enough, ends up somewhere at the bottom of the Marianas Trench.

20 Id. at 2135 (Gorsuch, J., dissenting). 
First, we know that as long as Congress makes the policy decisions when regulating private conduct, it may authorize another branch to "fill up the details" . . . .

Second, once Congress prescribes the rule governing private conduct, it may make the application of that rule depend on executive fact-finding ....

Third, Congress may assign the executive and judicial branches certain nonlegislative responsibilities .... So, for example, when a congressional statute confers wide discretion to the executive, no separation-of-powers problem may arise if "the discretion is to be exercised over matters already within the scope of executive power.”21 Talking about "important subjects" and matters of "less interest” was pretty clearly off the table for Justice Gorsuch.

It shouldn't be -- not for Justice Gorsuch nor for any other Justice who knows that the Constitution forbids subdelegation of legislative authority but who worries about giving judges seemingly open-ended power. There is far more to Chief Justice Marshall's test than meets the eye.

Lawyers had faced subdelegation questions for centuries before the Constitution was ratified, in the context of private-law agency arrangements. There are good reasons to think that the Constitution draws on private-law background norms for much of its meaning, and the subdelegation problem is an excellent candidate for elaboration in private-law terms. Once one fully understands that Chief Justice Marshall was drawing on those private-law norms in 1825, his approach reveals itself as far more structured, grounded in precedent, and law-like than may appear at first glance from a simple reference to "important subjects” and matters of "less interest."

21 Id. at 2135-37 (Gorsuch, J., dissenting) (footnotes omitted). 
Thus, Justice Gorsuch does not need to run away from Chief Justice Marshall’s inquiry; he simply needs to flesh out its private-law background, which does not leave judges free to roam through their personal preferences. There was law regarding subdelegation in the eighteenth and nineteenth centuries, and there is every reason to think that the Constitution's subdelegation principle is grounded in that law. A test for subdelegation based on eighteenth-century agency law is not only correct as a matter of original meaning; it is judicially manageable. Indeed, it is at least as judicially manageable as Justice Gorsuch's alternative three-principle structure for assessing subdelegations.

The bottom line is that a distinction between "important subjects" and matters of "less interest" --properly understood, as Chief Justice Marshall surely understood it, as a shorthand reference to principles of founding-era agency law -- is both theoretically and practically sound as a test for identifying unconstitutional legislative subdelegations.

Part I fleshes out the real meaning of Chief Justice Marshall's cryptic-at-first-glance comments in Wayman, suggesting how the Constitution's original meaning, which was aptly if tersely reflected in Wayman, lends itself to a legally rigorous reconstruction of the subdelegation doctrine. Part II compares that original meaning to Justice Gorsuch’s alternative formulation, suggesting some similarities and a few important differences. Part III briefly explains that the subdelegation doctrine cannot be treated wholly apart from the general size and scope of the federal government; Justice Gorsuch’s claim that the subdelegation doctrine is independent of those matters $^{22}$ is simply not correct. Part IV ruminates about one possible way to frame the

22 See id. at 2145 (Gorsuch, J., dissenting) ("Nor would enforcing the Constitution's demands spell doom for what some call the 'administrative state.' The separation of powers does not prohibit any particular policy outcome, let alone dictate any conclusion about the proper size and scope of government .... Congress is hardly bereft of options to accomplish all it might wish to achieve. It may always authorize executive branch officials to fill in even a large number of details, to find facts that trigger the generally applicable rule of conduct specified in a statute, or to exercise non-legislative powers.”). 
subdelegation problem in a fashion that will not spook Justices who have absorbed the mindset that the normative principle of "judicial restraint" trumps constitutional meaning in a large set of real-world cases.

In sum, the Supreme Court does not need to create a non-subdelegation doctrine. It needs only to rediscover it.

As a matter of original meaning, ${ }^{23}$ in order to figure out the constitutional test for when congressional grants of discretion to other actors amount to forbidden subdelegations of legislative power, one needs to know from where the Constitution's subdelegation principle comes. The source of the principle will have much to say about its content.

First, one could try to derive the subdelegation principle from the "civics book" model of enumerated institutional powers: The President and the federal courts cannot exercise legislative powers because they are not granted any such powers (beyond the President’s presentment powers and whatever common-law-fashioning powers the courts possess by virtue of the "judicial Power”). Nor, the argument continues, does Congress have an enumerated power to subdelegate its legislative powers to other actors. Hence, the Constitution's basic scheme of enumerated powers implies a principle of non-subdelegation. That is essentially the core of Justice Gorsuch’s

23 There are, of course, a great many versions of "original meaning." The version employed here locates meaning in the hypothetical intentions of the hypothetical author of the Constitution ("We the People"), which operationally is equivalent to the understandings that would have been held by a reasonable intended reader of the document in (for purposes of the non-subdelegation doctrine) 1788. Fleshing out the characteristics of the intended reasonable reader is a task for another life. See Gary Lawson, Reflections of an Empirical Reader (Or: Could Fleming Be Right this Time?), 96 B.U. L. REV. 1457 (2016). Fortunately, I doubt whether the differences among versions of original meaning matter much for purposes of the nondelegation doctrine; I suspect that all of those versions will converge to a common core of meaning in this context. 
argument in Gundy for a non-subdelegation principle, ${ }^{24}$ and some very talented scholars have at times made arguments along these lines. ${ }^{25}$ The possible counter to this argument, however, might claim that (1) Congress does indeed have power to give other actors as much discretion as Congress wants to give them by virtue of the Necessary and Proper Clause ${ }^{26}$ and (2) once Congress enacts such a statute granting extensive or even limitless discretion to the President or the courts, the other actors are formally exercising "executive" or "judicial" power in carrying into effect the congressional instruction to, in essence, make the law. ${ }^{27}$ Thus, for the "civics book" argument to succeed, it must be the case that there is some substantive principle lurking in the Constitution that would make it not "proper" for Congress to grant too much discretion to other actors (and/or not part of the executive and judicial powers for those actors to exercise that discretion). The "civics book" argument is thus a fine logical structure, but it is incomplete without something to fill in that missing substantive principle.

A second argument against subdelegation of legislative authority would look to the Constitution's elaborate mechanisms for electoral accountability. Much of the Constitution is devoted to the procedures for selecting members of Congress and for determining the electorate that will perform the selecting. Surely, one might reason, the Constitution would not care so much how members of Congress get selected if they aren’t actually supposed to make the key decisions.

24139 S.Ct. at 2133 (Gorsuch, J., dissenting).

25 See, e.g., Lawson, supra note 11; Gary Lawson, Discretion as Delegation: The "Proper" Understanding of the Nondelegation Doctrine, 73 GEO. WASH. L. REv. 235 (2005).

26 U.S. ConsT. art. I, § 8, cl. 18 ("The Congress shall have Power ... To make all Laws which shall be necessary and proper for carrying into Execution the foregoing Powers, and all other Powers vested by this Constitution in the Government of the United States, or in any Department or Officer thereof”).

${ }^{27}$ For the classic statement of this position, see Posner \& Vermeule, supra, note 1. 
Marty Redish’s "political commitment” principle reflects a variant of this argument, ${ }^{28}$ as does David Schoenbrod's accountability-based “consent of the governed” approach. ${ }^{29}$ The counter to this argument is that members of Congress are elected in order to exercise their constitutional powers. If one of those constitutional powers is the power to grant unlimited discretion to other actors, then that is simply part of the package of powers which they were elected to exercise. Again, the real issue is whether there is some underlying substantive limitation on Congress's ability to punt away too much of its decision-making responsibility.

The third argument, and the one to which the others eventually must reduce, directly locates a non-subdelegation principle in the very fiber of the Constitution. It took me twenty years plus the indispensable Rob Natelson to grasp this point, but the real ground for the Constitution's nonsubdelegation principle is the nature of the Constitution as a particular kind of legal instrument. Chief Justice Marshall grasped this point in 1825, even though he did not expressly articulate it, and his grasp generated the test that he so tersely announced. We must today understand what Chief Justice Marshall took for granted in 1825.

The argument starts with something very basic: No text can expressly contain all of the rules for its own interpretation. Even if it purported to do so, one would need external rules of interpretation to tell how to interpret the text's internally expressed rules of interpretation - even if only to tell one to treat those internally expressed rules seriously rather than metaphorically, frivolously, or sarcastically. There are always background norms of interpretation at work in any act of communication, whether it is a dramatic poetry reading, a conversation between spouses, or

28 See Martin H. Redish, The Constitution as Political Structure 136-37 (1995).

29 See David Schoenbrod, Consent of the Governed: A Constitutional Norm that the Courts Should Substantially Enforce, 43 HARV. J.L. \& PUB. POL’Y 213 (2020). 
a lawyerly study of the United States Constitution. Those background norms will differ depending on what kind of document one is interpreting; the background rules for interpreting poems are not going to be identical to the background rules for interpreting health care proxy designations or end-of-life instructions. ${ }^{30}$

The Constitution is not a poem. Nor is it a chain novel, a diary, or a script for a Monty Python sketch. It is a legal document of some sort, written in a dialect of English that one might call "legal English.”31 Background rules of interpretation that would encourage one to look for metaphor, irony, or sarcasm in the constitutional text are very unlikely to help discern that text's actual communicative meaning (though such background rules might be well suited to discerning the meaning of certain poems, diaries, or scripts for Monty Python sketches).

The universe of documents known as legal documents, of course, comes in all different shapes and forms, from contracts to wills to health care proxies. Granting that these are all materially different in some respect from poems, diaries, or Monty Python scripts: Where within this universe of legal documents does the Constitution best fit?

I have co-written a book on exactly that question, ${ }^{32}$ which argues that the best answer is that the Constitution looks most like a power of attorney, with a corporate charter coming in a close second (and a trust instrument running a distant third). My co-author and I are planning a revised second edition which will focus less on the distinctions among those options than on their similarities. As it happens, that debate matters less to the subdelegation puzzle than it does to

30 For more on this crucial point about the relationship between background interpretative rules and documentary

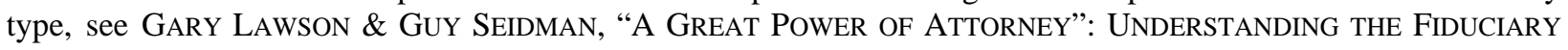
CONSTITUTION 8-11 (2017).

31 See John O. McGinnis \& Michael B. Rappaport, The Constitution and the Language of the Law, 59 WM. \& MARY L. REV. 1321 (2018).

32 See LAWSON \& SEIDMAN, supra note 30. 
some other questions of constitutional meaning, because all of the plausible characterizations of the Constitution - including the plausible characterization of "sui generis" - locate it somewhere within a family of instruments that one can broadly call "fiduciary" instruments. ${ }^{33}$

The Constitution's grants of power to Congress in Article I (and in Articles IV and V as well) are, in form, the written record of a delegation of authority from a principal, "We the People," to an agent, "a Congress of the United States." It is a delegation of a kind that would be familiar to any eighteenth-century observer who had encountered instruments such as powers of attorney and which was certainly familiar to the Committee of Detail consisting of four attorneys and a businessman, all of whom no doubt had a classical education that emphasized a fiduciary account of government. ${ }^{34}$ Just as one could delegate to a private agent management authority over a portion of one's affairs, such as the running of a farm or the sale of goods abroad, the Constitution represents a delegation to a public agent (or series of agents) of some authority over a portion of We the People's affairs. And eighteenth-century fiduciary delegations, in any context, carried a

33 In a forthcoming article, Professors Sam Bray and Paul Miller argue, with considerable force, that there was no general category of "fiduciary" instruments known to lawyers in the late eighteenth century. See Samuel L. Bray \& Paul B. Miller, Against Fiduciary Constitutionalism, 106 VA. L. REV. - (2020) (forthcoming). They claim instead that there was a variety of power-conferring instruments in specific settings, and it was not until considerably after the ratification of the Constitution that those disparate documents were categorized and synthesized with the label "fiduciary." That is all true; no one in 1788 would think to write a treatise on something called "fiduciary law." Indeed, some legal dictionaries of that time did not even contain entries for the term "agent." Nonetheless, the categorization of the Constitution as a fiduciary instrument is descriptively accurate. The reason why later writers were able to synthesize these disparate documents into a modern category of "fiduciary instruments" is because there was something there to synthesize. There were certain characteristic features of those documents immanent in the structure of the law, even if there was no established terminology for expressing those features in the form of a general theory. There was no vocabulary of fiduciary law in the eighteenth century, but there was a substance of fiduciary law in the eighteenth century. Rob Natelson has exhaustively catalogued the core features of eighteenth-century fiduciary (though they did not call it that at the time) law. See Robert G. Natelson, The Legal Origins of the Necessary and Proper Clause, in Gary Lawson, Geoffrey P. Miller, Robert G. Natelson \& Guy I. Seidman, The Origins of the Necessary and Proper Clause 57-59 (2010); Robert G. Natelson, Judicial Review of Special Interest Spending: The General Welfare Clause and the Fiduciary Law of the Founders, 11 Tex. Rev. L. \& Pol. 239 (2007). Even without the modern vocabulary, a reasonable eighteenth-century observer could and would see elements in the Constitution that resemble the elements in a power of attorney, a corporate charter, and so forth.

34 See LAWSOn \& SEIDMAN, supra note 30, at 31-37; CARL J. Richard, The Founders AND the Classics: GreECE, ROME, AND THE AMERICAN ENLIGHTENMENT (1994). 
principle against subdelegation - the more appropriate term than nondelegation, given the initial delegation of authority to Congress -- in their wake.

Authorities for this proposition about a presumptive lack of authority for agency subdelegation are numerous - and, as far as I can tell, unanimous. Matthew Bacon's enormously influential $A$ New Abridgement of the Law, ${ }^{35}$ first published in 1730, explained: "One who has an Authority to do an Act for another, must execute it himself, and cannot transfer it to another; for this being a Trust and Confidence reposed in the Party, cannot be assigned to a Stranger whose Ability and Integrity were not so well thought of by him for whom the Act was done; therefore an (a) Executory having Authority to sell, cannot sell by Attorney."36 Note that this maxim is not confined to any specific kind of instrument; it describes a rule applicable to all instances of what today we would call fiduciary authority. Six further editions of the treatise, extending into the middle of the nineteenth century, repeated the maxim, with examples drawn from contexts as varied as powers of appointment and guardianships. ${ }^{37}$

Early nineteenth-century treatises on agency law said the same thing. Samuel Livermore, a noted agency-law theorist, ${ }^{38}$ wrote in 1818: “An authority given to one person cannot in general be delegated by him to another; for being a personal trust and confidence it is not in its nature transmissible, and if there be such a power to one person, to exercise his judgment and discretion,

35 On the underappreciated significance of Bacon's Abridgement, see LAWSON \& SEIDMAN, supra note 30, at 113.

361 Matthew Bacon, A NeW Abridgement of the Law 203 (1730). "Attorney” in this context does not mean a lawyer. It simply means someone who is authorized to act on behalf of another - essentially what today we would call an "agent." See Giles JaCoB, A New LAw Dictionary ( $6^{\text {th }}$ ed. 1750) (defining attorneys as "those Persons who take upon them the Business of other Men, by whom they are retained").

37 See LAWSON \& SEIDMAN, supra note 30, at 113-14.

38 Noted enough to be cited by the United States Supreme Court in the twenty-first century, see Domino's Pizza, Inc. v. McDonald, 546 U.S. 470, 475 (2006), and cited by the Court at least eight times in the nineteenth century. 
he cannot say, that the trust and confidence reposed in him shall be exercised at the discretion of another person." ${ }^{39}$ Livermore's treatise offers examples from case law involving attempts at subdelegation in contexts ranging from powers of appointment in wills, in which the holder of the power tries to designate another person to exercise it, ${ }^{40}$ to the lack of privity between merchants and subdelegees in the absence of express authority on the part of the agents to subdelegate power, ${ }^{41}$ to the lack of authority of factors and supercargoes to entrust sale of goods to subagents without the express consent of their principals. ${ }^{42}$ Joseph Story's even more famous treatise on agency law similarly explained: "one, who has a bare power or authority from another to do an act, must execute it himself, and cannot delegate his authority to another; for this being a trust or confidence reposed in him personally, it cannot be assigned to a stranger, whose ability and integrity might not be known to the principal or who, if known, might not be selected by him for such a purpose." ${ }^{43}$ Story cites, as examples, many of the same cases that appear in Livermore's treatise. James Kent piled on: “An agent, ordinarily, and without express authority, has not power to employ a sub-agent to do the business, without the knowledge or consent of his principal. The maxim is, that delegatus non potest delegare, and the agency is generally a personal trust and confidence which cannot be delegated ...."44 I am not aware of any eighteenth- or nineteenth-

391 Samuel Livermore, A Treatise on the Law of Principal and Agent ANd of Sales by Auction 54 (1818).

40 See Ingram v. Ingram, 26 Eng. Rep. 455 (1740).

41 See Cockran v. Irlam, 105 Eng. Rep. 393 (1814).

42 See Catlin v. Bell, 171 Eng. Rep. 59 (1815).

43 Joseph story, Commentaries on the Law of Agency, as a Branch of Commercial and Maritime JURISPRUDENCE § 13, at 14 (1844).

442 James Kent, Commentaries on American LaW 496 (1827). It is possible that Kent and others misunderstood the Latin maxim that they invoked. See Patrick W. Duff \& Horace E. Whiteside, Delegata Potestas Non Potest Delegari: A Maxim of American Constitutional Law, 14 CoRnell L. ReV. 168 (1929); Sean P. Sullivan, Power, but How Much Power? Game Theory and the Nondelegation Principle, 104 VA. L. REV. 1229, 1248 (2018) (relying on the Duff/Whiteside account). That question is important as a matter of legal history but unimportant for interpretative 
century source that contradicts these authors on the basic agency law of subdelegation. "The founding-era rule against subdelegation of delegated agency authority is as clearly established as any proposition of law can be established.”45 Founding-era private-law lawyers understood very well the problem of subdelegation of authority.

Once the Constitution is seen in agency-law terms, the rule against subdelegation follows as a matter of course, as it would for any document in the family of fiduciary instruments. The Constitution's text and structure confirms and reinforces this fundamental fiduciary principle. Text- and structure-based arguments against subdelegation -- such as the ones that I made for twenty years before meeting Rob Natelson and that Justice Gorsuch was making in Gundy -- are not wrong. Far from it. They are simply incomplete. The same is true of arguments from the dictates of representative government. The substantive content of the subdelegation principle, which every textual and structural feature of the Constitution confirms and reconfirms, comes from the nature of the Constitution as a particular kind of legal instrument, for which a rule against subdelegation is the background presumption. ${ }^{46}$ The Constitution contains a principle against subdelegation because it is the kind of document that contains a principle against subdelegation. That is why Chief Justice Marshall could say with such assurance that "[i]t will not be contended that Congress can delegate to the Courts, or to any other tribunal, powers which are strictly and exclusively legislative.” 47 To anyone who sees the Constitution as a kind of fiduciary instrument, the conclusion is obvious.

\footnotetext{
theory. What matters for understanding founding-era agency law is what reasonable founding-era legal actors would have believed about the referents of fiduciary concepts, not whether they would have been historically right to believe it.

45 LAWSON \& SEIDMAN, supra note 30, at 114.

46 This is an interpretative claim, not a normative claim. It is a claim about the meaning of a document, not about the right or wrong way to run a society.
} 
But identifying a basic principle against subdelegation of legislative authority is only the beginning. Just as well established in the founding era as the principle against agency subdelegation were the exceptions to this general rule. The rule against subdelegation of agency authority was a presumptive rule, not an absolute one. There were three key principles that carved out a space for permissible subdelegation by agents.

First, parties could expressly authorize any kind or degree of subdelegation that they wished in the agency instruments themselves: "an authority may be delegated to another, where the attorney has an express authority for that purpose." ${ }^{48}$ The crucial term is "express." Given the strong background interpretative rule against subdelegation, "when it is intended, that an agent shall have a power to delegate his authority, it should be given to him by express terms of substitution." 49 This exception has no application to the United States Constitution. There is no express authorization in the Constitution for congressional subdelegation of delegated legislative authority. The only linguistically plausible source would be the Necessary and Proper Clause, and that does not even come close to constituting an express authorization for subdelegation. ${ }^{50}$ Indeed, if anything, the Necessary and Proper Clause affirmatively negates any such inference, though that is a tale for another time and a different scholarly life. ${ }^{51}$

\footnotetext{
47 Wayman v. Southard, 23 U.S. (10 Wheat.) 1, 42 (1825).

48 LiVERMORE, supra note 39, at 55. Again, see supra note 36, an "attorney" in this context is simply an agent and not necessarily a lawyer.

49 STORY, supra note 43, at 15-16.

50 For an example of what an express authorization for subdelegation would look like, see FlOyd R. MECHEM, A TREATISE ON THE LAW OF AGENCY 299 (1914).

51 See, e.g., Lawson, supra note 11.
} 
Second, the normal background rule against subdelegation might not hold in specific contexts where there is a clear custom or tradition of allowing subdelegation, so that a particular instrument in such a setting most likely contemplates an arrangement outside the usual expectations of fiduciary law. An 1814 English case (cited by both Livermore and Story), while finding no privity of contract between a merchant and a subagent when the agent had no express authorization to subdelegate authority, said in dictum that the answer might have been different if there had been a "usage of trade such as to authorize one broker to put the goods of his employer into the hands of a sub-broker to sell.”52 Other cases also make reference to customs and practices permitting subdelegation, such as a custom of subdelegating collection of notes to local banks when the debtor is at a distance. ${ }^{53}$ Again, this will not work to validate subdelegation of congressional legislative authority, if only because there could not possibly be a custom or tradition of subdelegation in a regime of separated powers such as that created by the Constitution when there was no established history of such separation-of-powers regimes from which to induce a custom or tradition.

The third principle concerns the kinds of tasks that were, and were not, subject to the background presumption against subdelegation. If you hire a factor and/or supercargo to sell your goods overseas, is the supercargo expected personally to pilot the boat, swab the decks, and cook the fishcakes on the journey? Must the factor personally deliver any necessary title documents to the local recorder? The agency instrument can, if the parties so choose, specifically address these questions - and can give any answer they please, including making the supercargo swab the decks - but what if the instrument is silent? The background rule was that subdelegation was presumptively forbidden for those discretionary aspects of the tasks at hand that involve a

52 Cockran v. Irlam, 103 Eng. Rep. 393, 394 (1814).

53 See, e.g., Dorchester \& Milton Bank v. New England Bank, 5 Mass. 177, 188 (1848). 
significant element of judgment but presumptively allowed for ministerial or minor aspects of the tasks. What counted as discretionary or ministerial would vary with the particular circumstances of each arrangement. A collection agent can allow a subdelegee to deliver an eviction notice, ${ }^{54} \mathrm{a}$ general shipping agent can let subdelegees sign bills of lading, ${ }^{55}$ and insurance agents can let clerks sign policies. ${ }^{56}$ The assumption (subject always to clarification or alteration by the terms of the instrument) is that the parties intend to allow a measure of subdelegation on less important matters in order to facilitate the efficient accomplishment of the chief ends of the instrument. In the words of an early twentieth-century article on agency law (written by a notable treatise writer), "there are many cases wherein from the nature of the duty, or the circumstances under which it is to be performed, the employment of subagents is imperatively necessary, and the principal's interests will suffer if they are not so employed. In such cases, the power to employ the necessary subagents will be implied." ${ }^{57}$ As Joseph Story summarized it,

But there are cases, in which the authority [to subdelegate] may be implied; as where it is indispensable by the laws, in order to accomplish the end; or it is the ordinary custom of trade; or it is understood by the parties to be the mode, in which the particular business would or might be done .... In short, the true doctrine, which is to be deduced from the decisions, is, (and it is entirely coincident with the dictates of natural justice,) that the

\footnotetext{
54 See, e.g., McCroskey v. Hamilton, 108 Ga. 640, 34 S.E. 111 (1899).

55 See, e.g., The Guiding Star, 53 F. 936 (S.D. Ohio 1893).

56 See, e.g., Bodine v. Exchange Fire Ins. Co., 51 N.Y. 117 (1872).

57 Floyd R. Mechem, Delegation of Authority by an Agent, 5 Mich. L. REv. 94, 99 (1906). In some circumstances, the end can only be accomplished through subdelegation, as where the agent is not a licensed attorney or auctioneer but such a person is necessary to complete the transaction. In those circumstances, the assumption is that subdelegation to the appropriate professionals was contemplated by the parties. See, e.g. Strong v. West, 110 Ga. 382, 35 S.E. 693 (1900).
} 
authority is exclusively personal, unless, from the express language used, or from the fair presumptions, growing out of the particular transaction, or of the usage of trade, a broader

power was intended to be conferred on the agent. ${ }^{58}$

If any of this sounds vaguely familiar, it is because one good way to express the principle expounded by Story is to say that power to subdelegate (absent express authorization or custom to the contrary) is strictly forbidden with respect to important matters but will be inferred (again absent express provision or custom to the contrary) with respect to matters of less interest. Chief Justice Marshall, in Wayman v. Southard, was faithfully translating the private law of agency into the Constitution - just as he had done six years earlier in McCulloch v. Maryland when he construed the Necessary and Proper Clause as a standard agency-law incidental powers clause familiar from numerous private-law contexts. ${ }^{59}$ As a matter of original meaning, that was exactly the right move, to the extent that the Constitution's character as a fiduciary instrument draws into play the basic rules for interpreting fiduciary instruments.

So, how would a Marshallian determine what counts as a matter of "less interest"? Private law will not always provide a definitive answer, if only because the inquiry of what is more and less important depends heavily on context. The ultimate inquiry is to figure out what is either so incidental or so absolutely essential to a decision that one must reasonably presume that the principal intends for the agent to subdelegate at least some of the authority. Notice that the inference of authority to subdelegate occurs at both tails of the distribution: Intent to authorize

58 STORY, supra note 43, at 16-17.

59 For the full story on McCulloch and agency law, see LAwSON \& SEIDMAN, supra note 30, at 87-90; Gary Lawson \& David B. Kopel, Bad News for Professor Koppelman: The Incidental Unconstitutionality of the Individual Mandate, 121 YALE L.J. ONLINE 267, 277-79 (2011). For the seminal study of the agency-law character of the Necessary and Proper Clause, see Robert G. Natelson, The Agency Law Origins of the Necessary and Proper Clause, 55 CASE WESTERN RESERVE L. REV. 243 (2004). 
some measure of subdelegation is inferred when the task at hand seems to require it as well as when the task is so routine that it cannot possibly matter who performs it. The agent must personally perform those tasks that fall within the middle of the curve. The shape of the curve will vary with the context; what is permissible in one setting may well be flatly forbidden in another.

While crisp, Scalia-like rules are therefore not likely to emerge from the common law of agency, some examples from the eighteenth- and early nineteenth-century cases may be instructive. Start with some easy cases that illustrate clear instances of permissible and impermissible subdelegation and then move towards the middle of the curve.

For an example of readily permissible subdelegation, one can look to Goswill v. Dunkley, ${ }^{60}$ decided sometime before $1748 .{ }^{61}$ Plaintiff gave the defendant custody of a watch and a sword to take to Porto Bello (which I believe is in Panama) to sell, thus making the defendant the selling agent for the plaintiff. The defendant agent claimed that in order to safekeep the sword and watch, "he put them into the warehouse of the South-Sea Company." 62 There was a break-in at the warehouse, the goods were stolen, and the plaintiff sued the defendant. Plaintiff argued that "these goods were delivered to the defendant under a special and particular trust; and that he could not defend himself against the plaintiff's demand, by shewing that he had lodged them in a warehouse, which was a committing them to the care of a third person ...."63 The court disagreed and ruled for the defendant. That has to be right. It seems obvious that the parties did not contemplate that the sword and watch would never leave the agent's direct physical custody until the instant of sale

\footnotetext{
6093 Eng. Rep. 779.

61 The case report is undated, but the reporter volume covers a time period that ends in 1748 .

62 Id.

63 Id. at $779-80$.
} 
(though one can imagine contracts, and perhaps contexts such as a valuable ring, that so require). Defendant surely could not subdelegate the task of finding an appropriate buyer, negotiating the price, and so forth, but storing the goods in a warehouse seems no different from piloting the ship to Panama. Defendant would be responsible for exercising due care in the selection of a subdelegee, ${ }^{64}$ but this seems clearly to be the kind of function that all parties could reasonably expect to be handled by other agents. In Chief Justice Marshall’s terms, in an agency arrangement for the sale of goods overseas, the actual physical storage of the goods is a matter of "less interest" - though the selection of the appropriate place of storage may well be an "important subject" that the agent must personally perform.

For an example of clearly forbidden subdelegation, look no further than the 1740 decision in Ingram v. Ingram. ${ }^{65} \mathrm{Mr}$. Ingram had been given "a power of disposing of a reversionary interest in copyhold land ... in such shares and proportions as he should think fit among the issue of the marriage, and for want of such appointment by the husband, to his right heirs . ..”66 He could execute the power by deed or by will. In his will, Mr. Ingram, "reciting the power under the articles and settlement, delegates it to his wife, that she may, in such shares and proportions as she shall think proper, dispose of it between his son and daughter ...."67 The court invalidated the purported subdelegation: "This must be considered as a power of attorney which could be executed

\footnotetext{
64 The court noted: "if the warehouse was not a place of safe custody, that should have been replied . ..." Id. at 780. I explore the difficult issues surrounding selection of appropriate subdelegees in another article. See Gary Lawson, The Fiduciary Social Contract, -- SOCIAL PHIL. \& POL’Y - (forthcoming 2021).

6526 Eng. Rep. 455 (1740).

66 Id.

67 Id.
} 
only by the husband, to whom it is solely confined, and is not in its nature transmissible or delegatory to a third person ...."68

These are polar cases, to be sure, but they have analogues in the Constitution. Consider the grant to Congress of the power "[t]o coin Money, [and] regulate the Value thereof."69 Does the first part of the grant mean that members of Congress must personally work in the mint stamping coins? ${ }^{70}$ Obviously not. The "important subject” in that grant of power is the authorization to produce coins, the specification of the metals to be employed, the denominations to be issued, and so forth. The actual coining or minting is, in this context, a ministerial task, or at least a matter of "less interest," and Congress would be within its authority to subdelegate to executive agents the power to "fill up the details" of the actual minting process. On the other hand, a subdelegation to executive agents of the power to fix the value of the coins goes to the heart of what the provision is all about - namely, to "regulate the Value thereof.” Subdelegating that primary authority to executive agents would be like subdelegating the authority to distribute the reversion in Ingram $v$. Ingram. There are easy cases to be found in the Constitution as well as in the common law of agency. For some problems, one needs only, as Justice Story put it, “the dictates of natural justice,” sprinkled with a modicum of common sense and some attention to the terms and purposes of the agency arrangement.

Now consider some cases that are not necessarily so easy. Two early nineteenth-century cases are especially instructive.

\footnotetext{
68 Id.

69 U.S. CONST. art. I, § 8, cl. 5.

70 This example actually came up in the 1791 postal debates in Congress. See 2 ANNALS OF ConG. 230-31 (1791) (statement of Rep. Sedgwick).
} 
In Catlin v. Bell, ${ }^{71}$ the plaintiff entrusted with the defendant shipper some hats to be sold in the West Indies. "It was then stated, that the defendant not being able to sell the goods in the island to which they were destined, had sent them to the Caraccas, in search of a market, where they had been destroyed by an earthquake."72 If the earthquake had happened in the assigned port of destination while the hats were in the control of the shipper, presumably the shipper would not have been liable for that act of God (unless the contract made the agent strictly liable, which seems unlikely). It was held, however, "that there being a special confidence reposed in the defendant with respect to the sale of the goods, he had no right to hand them over to another person, and to give them a new destination.”73 Thus, even though the agent may have thought - and sincerely thought - that he was serving the best interests of the principal by trying to get the best price, that alone would not justify entrusting the items to someone else to perform the central task of selling the goods. Here, the "important subjects" were both the shipping and sale of the goods, and neither of those elements could be subdelegated without express permission or custom to support it. A matter of "less interest" would surely be the storage of the goods pending sale; had the defendant responsibly chosen a warehouse in the West Indies and the goods been stolen from that warehouse, the defendant presumably would not have been liable absent a showing of negligence in the choice of warehouseman.

Now consider Bromley v. Coxwell. ${ }^{74}$ Bromley sent Coxwell to India to sell "one hundred engravings from his plate of His Majesty on horseback," 75 hoping to get at least a guinea for each.

\footnotetext{
71171 Eng. Rep. 59 (1815).

72 Id.

73 Id.

74126 Eng. Rep. 1372 (1801).

75 Id.
} 
Bromley significantly overestimated his artistic talent, His Majesty’s overseas popularity, or both, because Coxwell in Calcutta was able to sell only one print for just three shillings and five pence (about one-sixth of a guinea, if I calculate correctly). ${ }^{76}$ Coxwell then tried selling them in Madras "but with no better success."77 At that point, Coxwell "left the residue in the hands of an agent at Madras to be disposed of by him ....”78 Upon Coxwell's return to England, Bromley sued him for conversion. Bromley won at trial but lost on appeal. To some extent, the case turned on the appropriateness of conversion as a remedy, but all three appellate judges at least doubted whether there was any liability. The authorizing language in the agency instrument was as follows:

"William Bromley agrees to send out by James Coxwell one hundred engravings from his plate of His Majesty on horseback under these conditions, that provided James Coxwell can dispose of any one or all of them at above one guinea each, he the said James Coxwell is to be accountable to William Bromley on his return to England, for as many as he may dispose of at one guinea each; and William Bromley agrees to take all or as many as may be returned by the said James Coxwell, provided he the said James Coxwell cannot sell them in India or at any other port he may touch at, without expecting any sum from James Coxwell, or making any charge; and William Bromley further agrees to and authorizes to sell them for whatever they may fetch, if not more than one guinea may be offered for them separately."79

\footnotetext{
76 Coxwell was fully authorized to take the lower price. See id. (“ 'William Bromley further agrees to and authorizes to sell them for whatever they may fetch, if not more than one guinea may be offered for them separately' ”).

77 Id.

78 Id.

79 Id.
} 
Judge Heath remarked that "I do not see why he [Coxwell] was not at liberty to leave them with an agent to be sold"; Judge Rooke thought it was fine that "[t]he Defendant left them in India judging for the best"; and Judge Chambre said that "[t]he agreement does not express the Defendant shall sell the goods himself; it seems therefore that the delivery to his agent was within the terms of the agreement." ${ }^{80}$ There is obviously much that we do not know about the context of the arrangement from the very brief case report. Was Coxwell known to be a a factor? Was Coxwell just a traveler taking the prints to India? Did Coxwell run an import-export business with multiple locations, so that the use of subagents would be taken for granted? We do not know (or at least I do not know). All we know for sure is that the court was willing to infer a power to subdelegate the sale of the prints from the absence of any specification that the task was to be performed by Coxwell. There was obviously something in this arrangement that muted to some extent the baseline rule against subdelegation. The "important subject" was apparently getting the goods to India for sale; how and where they were sold was evidently a matter of "less interest." The language of the instrument, to be sure, does perhaps lend itself to this construction: the essence of the agreement is "Get these prints to India and see if you can sell them - for anything at all however and wherever you can manage to do it.” In that context, subdelegation to effectuate the sales seems a natural consequence of the arrangement.

Do these cases yield a crisp line that can always be drawn between what is important and what is of less interest? Of course not. Relatively few constitutional doctrines have lines so crisp and clear that some element of judgment is never necessary. The point is only that courts have been exercising judgment about subdelegation of agency authority for a very long time. This is

\footnotetext{
$80 \quad$ Id. at 1373.
} 
not a novel inquiry or one with no guideposts or analogies upon which to draw. It is a distinctively legal inquiry.

In light of the cases, here is one tentative thought about the application of these principles to one particular Article I power. A context in which power to subdelegate has often been found concerns collection of debts in distant locations - which was obviously a major issue in earlier times without instantaneous money transfers and communication, when debt collection, and even the negotiation of notes and bills of exchange, had to be done in person. Authorization of an agent to collect a debt or transfer a note would normally carry with it power to designate an appropriate subagent in the debtor's or transferee's jurisdiction. ${ }^{81}$ There are circumstances, in short, in which a local subagent is likely to have knowledge and access that is not readily available to the prime agent. If that is an expected state of affairs, one might reasonably presume that the parties to the agreement would anticipate some measure of subdelegation to local agents to take advantage of that specialized local knowledge. Where the task depends on general skill and knowledge, however, rather than localized skill or knowledge, the baseline presumption against subdelegation would hold.

All of this is potentially relevant to the Constitution because some of Congress's enumerated powers require uniform, nationwide application and some of them do not. In some instances, the requirement of uniformity is express: With respect to the taxing power, “all Duties, Imposts and Excises shall be uniform throughout the United States"; ${ }^{2}$ Congress has power "[t]o establish an uniform Rule of Naturalization, and uniform Laws on the subject of Bankruptcies throughout the

81 See, e.g., Thomas Wilson \& Co. v. Smith, 44 U.S. (3 How.) 763 (1845).

82 U.S. ConST. art. I, § 8, cl. 1. 
United States"; ${ }^{83}$ and Congress can implement the Constitution's full faith and credit requirement by "general Laws." ${ }^{4}$ For other powers, a uniformity requirement seems implicit: Could there really be a different value for federal coin in one State rather than another, or different federal patent laws for Texas and Wisconsin? Other powers, however, do not seem to require the same degree of uniformity. The power to "establish Post Offices and post Roads” ${ }^{85}$ surely does not force Congress to have the same number, or even proportion, of post roads and post offices in each State. More fundamentally, the power to "regulate Commerce ... among the several States" 86 does not contain an express uniformity requirement, and it is not obvious that it contains an implicit one. Indeed, the Constitution by implication denies any such general uniformity requirement by singling out one kind of commercial regulation - port regulations - for uniformity: "No Preference shall be given to any Regulation of Commerce or Revenue to the Ports of one State over those of another." ${ }^{87}$ Thus, it is possible that regulation of commerce is a field in which local knowledge and variation might be invaluable; the regulations appropriate to New York may not be appropriate for Wyoming. Does that provide a ground for applying the subdelegation doctrine less rigidly with regulation of commerce than with some other congressional powers? More specifically, could different air pollution rules be appropriate in New York than in Wyoming, with those different rules ascertained by subagents with local knowledge? Without answering these questions, I will just say that if one is looking for limiting principles to shield key elements of the

\footnotetext{
83 Id. art. I, § 8, cl. 4.

${ }^{84}$ Id. art. IV, § 1.

85 Id. art. I, § 8, cl. 7.

86 Id. art. I, § 8, cl. 3.

87 Id. art. I, § 9, cl. 6.
} 
modern regulatory state from a reinvigorated subdelegation doctrine, this is a possible avenue to explore.

This body of private-law agency doctrine gives content to Chief Justice Marshall’s distinction between the "important subjects" that the legislature must decide and those matters of "less interest” that can be subdelegated to others. In an agency instrument, the principal described with particularity what the agent was authorized to do. The agent presumptively had to perform those tasks, unless the nature of the instrument, the task, or both counseled otherwise. Unless it was a general power of attorney, agents did not have unlimited authority to act - and agents certainly did not have unlimited authority to allow others to act on behalf of the principal. The nature of the initial delegation limits, in legally defined ways, the nature of permissible subdelegations.

In the context of the Constitution, this cuts in two directions. On the one hand, it is probably not the case that all substantive executive rulemaking is per se a forbidden subdelegation; it will depend very much on the context. On the other hand, congressional grants of discretionary authority, whether rulemaking or adjudicatory, to other actors cannot be unlimited or so ill-defined in scope that no one-including the agency, the courts or Congress-could determine where they began or ended. Nor can those grants of authority go beyond what a sensible understanding of the tasks conferred on Congress permits. Reasonable people could perhaps disagree about hard cases, as reasonable judges and lawyers have been able to disagree about hard cases in the private-law context for centuries. But these are disagreements about law, not about policy or theories of government.

There was plenty of law on subdelegation in 1788 and 1825. One just needs to know where to look for it. 
In Gundy, Justice Gorsuch proposed three alternative principles as an account of the constitutional non-subdelegation rule. It is accordingly useful to see how Justice Gorsuch's principles compare, as a matter of both law and judicial manageability, to the agency-law doctrine of Chief Justice Marshall. As it happens, Justice Gorsuch’s principles loosely map onto the common-law categories for ascertaining permissible subdelegations, but the common-law categories are both better grounded in original meaning and better suited for judicial application.

Justice Gorsuch's third principle - that there is no subdelegation problem when Congress is simply helping execute powers already vested in other actors - very loosely corresponds to the common-law category of express authorization. The Necessary and Proper Clause allows Congress to make necessary and proper laws “for carrying into Execution,” inter alia, federal executive or judicial powers. If that is all that Congress is doing, it is doing something that the Constitution expressly permits it to do. That is not truly an express authority to subdelegate, because the powers being executed already exist in the executive and judicial actors, who do not need congressional authorization to do what the Constitution already entitles them to do. ${ }^{88}$ Thus, Justice Gorsuch is not really identifying a permissible domain of subdelegation - and the

${ }^{88}$ If the congressional laws purport to limit rather than facilitate the powers vested by the Constitution in the President or the courts, they are not laws "for carrying into Execution" those powers and thus are not authorized by the Necessary and Proper Clause; one does not "carry[] into Execution" a power by prohibiting or limiting its exercise. See David E. Engdahl, Intrinsic Limits of Congress' Power Regarding the Judicial Branch, 1999 B.Y.U. L. Rev. 75, 172-74. Indeed, the most important question in these contexts is not whether Congress has subdelegated legislative power by granting too much discretion but whether congressional attempts to limit rather than facilitate the discretion of executive or judicial actors improperly intrude on those actors' constitutional prerogatives. Can Congress fix the form of notice for judicial auctions? Determine the payment terms for winning bidders in such auctions? Tell courts what evidence they can and cannot admit into the record in those proceedings? Order courts to rule in favor of one particular party? A similar sequence of questions can be framed about congressional attempts to regulate the exercise of executive power - and the questions are no easier to resolve in that context. I have very tentatively explored these issues elsewhere, see Gary Lawson, Controlling Precedent: Congressional Regulation of Judicial Decision-Making, 18 Const. Commentary 191 (2001), and we can mercifully pass them over here. 
Constitution does not expressly provide one either. He is simply describing a context in which grants of discretion do not raise issues of subdelegation.

Justice Gorsuch’s second principle - that Congress can employ executive or judicial agents as fact-finders to determine the applicability of laws - has a very rough correspondence to the agencylaw exception for established customs and practices. The application of law often requires findings of fact. If, for example, a statute prescribes a calendar date for its own effectiveness, someone has to determine whether that specific calendar date has or has not arrived and thus whether the law is or is not in effect. If that seems trivial (how hard can it be to read a date off of a calendar?), it is precisely the triviality that makes it illustrative. In applying such laws, do executives or courts refer the matter to the legislature to determine whether the specified effective date has arrived? Of course not. They decide the matter for themselves. Isn't that sort of decision exactly what executing and/or construing laws is all about? Whatever custom or tradition of government action was incorporated into the Constitution's separation-of-powers scheme through the basic definitions of legislative, executive, and judicial power, surely this much at least qualifies: executing and judging includes the ascertainment of the factual conditions for application of a law.

Of course, once one moves beyond calendars as measures of a law's effective date, things start to get a bit cloudier. Suppose that the effective date of a law is prescribed in terms of events other than planetary motions, so that a law becomes or stays effective, say, upon the eruption of a volcano, or some other country continuing to respect American neutrality, or a foreign country not imposing reciprocally unequal or unreasonable tariffs on imported American goods. Someone has to determine whether the conditions for the law's effectiveness have been satisfied. Who does that? Again, executive and judicial agents customarily and traditionally perform that task. This is the category of so-called contingent legislation which Justice Gorsuch's second principle was 
describing, represented by a very large percentage of the pre-New Deal subdelegation cases in the Supreme Court. ${ }^{89}$ The question here is whether the principle, expressed in terms of either factfinding or custom, contains limits on the kinds of facts which Congress can charge executive or judicial agents with ascertaining. Calendar dates are at one extreme. At the other would be a law that prescribes its effective date to be "whenever the President [or perhaps the Attorney General] decides it should apply.” Can an executive or judicial actor's will be the triggering contingency for the effectiveness of a statute? And if the answer is no, are there other "facts" that are so openended or policy-laden that committing their determination to executive or judicial agents effectively makes those actors legislators? (Two Justices in 1892 thought that letting the President determine whether other countries had imposed "reciprocally unequal and unreasonable" trade restrictions on American products "certainly extends to the executive the exercise of those discretionary powers which the Constitution has vested in the law-making department.”90) Justice Gorsuch clearly wants to avoid how-much-is-too-much kinds of questions, but the category of contingent legislation may not lend itself to categorical judgments. No formulation of a test can eliminate the need for judgment, at some point in the process, about whether ascertainment of a contingent "fact" amounts to making the law. That is an issue under current doctrine, it would be an issue under Chief Justice Marshall’s test, and it would be an issue under Justice Gorsuch’s three principles. ${ }^{91}$

89 See, e.g., Cargo of the Brig Aurora v. United States, 11 U.S. (7 Cranch) 382 (1813); Marshall Field \& Co. v. Clark,143 U.S. 649 (1892); J.W. Hampton, Jr. \& Co. v. United States, 276 U.S. 394 (1928). For a discussion of these cases, see Lawson, supra note 11, at 361-69.

90143 U.S. at 699-700 (Lamar, J., dissenting).

91 Part of the reason why the contingent legislation - or "executive or judicial fact-finding" -- cases are so difficult is that the distinction between law and fact on which they are based is itself a conventional rather than metaphysical distinction. But pursuing that angle leads inexorably to a book-length discussion. See GARY LAWSON, EvidENCE OF THE LAW: PROVING LEgAL Claims (2017). 
The real action concerns Justice Gorsuch's first principle, which allows Congress to let executive or judicial agents "fill up the details." The quoted phrase comes from the end of a sentence in Wayman v. Southard: "The line has not been exactly drawn which separates those important subjects, which must be entirely regulated by the legislature itself, from those of less interest, in which a general provision may be made, and power given to those who are to act under such general provisions to fill up the details." ${ }^{92}$ Notice how Justice Gorsuch transforms the meaning of "fill up the details." In Wayman, the term applies only to, and indeed simply alternatively describes, matters of less interest. It is fine, says Chief Justice Marshall, to let agents "fill up the details" on those less important matters. But that does not mean that it is okay for Congress to let agents "fill up the details" on "important subjects." To the contrary, those "important subjects ... must be entirely regulated by the legislature itself." The key distinction for Chief Justice Marshall is thus not big pictures versus details. It is important subjects versus matters of less interest. Justice Gorsuch, however, omits the context when he explains that Congress can "accomplish all it might wish to achieve. It may always authorize executive branch officials to fill in even a large number of details ...."93 Chief Justice Marshall would disagree, and Chief Justice Marshall would be right. Congress can only authorize executive officials to fill in details, in either a large or small number, with respect to matters of "less interest." That surely does not cover everything that Congress "might wish to achieve."

Thus, the key rhetorical -and substantive - move for Justice Gorsuch is to give free-standing effect to a congressional ability to charge executive and judicial agents with filling up details. An agency-law based approach to subdelegation could potentially be considerably stricter, because

$92 \quad 23$ U.S. (10 Wheat.) at 43.

93139 S.Ct. at 2145 (Gorsuch, J., dissenting). 
the detail-filling capacity of sub-agents is not free-standing but is limited only to subjects that by their nature as matters of "less interest" can permissibly be charged to the discretion of subagents. Put another way, for Chief Justice Marshall and the agency-law view that he represents, "fill up the details" is somewhat of a throwaway embellishment on the true inquiry, which looks to the nature of the tasks in the context of the obvious purposes of the instrument in question. For Justice Gorsuch, "fill up the details" is the inquiry itself. That is not what the Constitution prescribes.

III

Justice Gorsuch was at pains to say that "[t]he separation of powers does not prohibit any particular policy outcome, let alone dictate any conclusion about the proper size and scope of government." ${ }^{94}$ In other words, says Justice Gorsuch, questions about the form of congressional statutes - the extent to which they grant discretion to other actors - is independent of questions about the content of congressional statutes - the extent of their regulatory reach. That is true up to a point - but only up to a point.

Go back to Justice Story's summary of the agency law of subdelegation. Justice Story said that authority to subdelegate will be implied "where it is indispensable by the laws, in order to accomplish the end.” The classic illustration would be a grant of authority to a non-lawyer agent to execute a transaction in which a lawyer's participation at some point is essential. The natural assumption is that the non-lawyer agent is authorized to hire a lawyer to perform that part of the task; otherwise, the initial delegation to the agent would be pointless. Or suppose that an agent is tasked with selling an item at auction, but the agent is not a licensed auctioneer. Must the agent

94 Id. (Gorsuch, J., dissenting). 
get an auctioneer's license, or is the obvious assumption that the agent will engage a licensed auctioneer and be responsible only for making an appropriate selection of a subagent? One might extend this reasoning a bit further to conclude that where subdelegation is practically as well as legally necessary to successful accomplishment of a task, we can presume that the principal intended to authorize the agent to subdelegate to the extent necessary to accomplish the prescribed ends.

Precisely such an argument, conducted in precisely those agency-law terms, emerged in the Second Congress in 1791 in connection with post roads. One big debate was whether Congress had to specify the path of the postal routes or whether it could leave that matter to executive discretion. ${ }^{95}$ Several representatives, including James Madison, vigorously argued that Congress constitutionally had to fix the routes. ${ }^{96}$ Madison's comments are especially pertinent, as they concern the extent to which necessity, in either a strict or loose sense of the term, can bear on the propriety of subdelegation:

However difficult it may be to determine with precision the exact boundaries of the Legislative and Executive powers, he was of opinion that those arguments ... [in favor of subdelegation to the President] were not well founded, for they admit of such construction as will lead to blending those powers to as to leave no line of separation whatsoever. The greatest obstacle to the due exercise of the powers vested in the

95 For a detailed account of that debate, see LAWSON \& SEIDMAN, supra note 30, at 118-23.

96 See, e.g., 2 AnNALS OF CONG. 229 (1791) (describing statement of Rep. Livermore) ("it is as clearly their [Congress's] duty to designate the roads as to establish the offices; and he did not think they could with propriety delegate that power, which they were themselves appointed to exercise"); id. at 231 (statement of Rep. Hartley) ("We represent the people, we are constitutionally vested with the power of determining upon the establishment of post roads; and, as I understand at present, ought not to delegate the power to any other person”); id. at 235 (statement of Rep. Vining) ("The Constitution has certainly given us the power of establishing post and roads, and it is not even implied that it should be transferred to the President”). 
Legislature by the bill, which has been mentioned, is the difficulty of accommodating the regulations to the various interests of the different parts of the Union: and this is said to be almost impracticable. But it may be remembered, that similar embarrassments appeared when the impost and tonnage bills were under consideration; on those subjects, the members were obliged to be governed, in a great degree, by mutual information and reciprocal confidence. In respect to the establishment and arrangements of the different ports of entry and clearance, and other objects, that was a business of much greater importance and difficulty than this; but it was accomplished. ${ }^{97}$

On the other hand, many representatives had no constitutional problem with letting the executive determine the postal routes. ${ }^{98}$ One recurring argument in favor of letting the President decide on the postal routes was precedent. Congress had previously imposed an excise tax on spirits, and to facilitate collection of the tax the country was divided by statute into fourteen districts, with each district consisting of a State "but subject to alterations by the President of the United States, from time to time, by adding to the smaller such portions of the greater as shall in his judgment best tend to secure and facilitate the collection of the revenue; which districts it shall be lawful for the President of the United States to subdivide into surveys of inspection, and the same to alter at his discretion." ${ }^{99}$ Representatives Bourne and Sedgwick both invoked this statute as precedent for the necessity of letting the President determine the paths of the post roads. ${ }^{100}$ Madison's response is

\footnotetext{
97 Id. at 238 (statement of Rep. Madison).

98 See, e.g., id. at 230-31 (statement of Rep. Sedgwick).

99 Act of Mar. 3, 1791, ch. XV, § 4, 1 Stat. 199, 200.
}

100 See 2 AnNAls of CONG. 232 (statement of Rep. Bourne) ("In passing the excise law, the House, not thinking themselves possessed of sufficient information, empowered the President to mark out the districts and surveys; and if they had a right to delegate such power to the Executive, the further delegation of the power of marking out the roads for the conveyance of the mail, could hardly be thought dangerous"); id. at 239 (statement of Rep. Sedgwick) ("Nothing more was in that instance done, than to define the powers and duties annexed to the offices, but the limits 
instructive: "The reference to the appointments and arrangements made by the Executive, pursuant to the powers delegated to the Executive by the excise law, cannot be considered as a parallel case; no similar exigency exists to justify a similar delegation .... Where is the necessity of departing from the principles of the Constitution in respect to the post office and post roads, more than in all other cases?”101 Madison thus questioned the factual predicate of the argument for necessity, but he conceded that necessity might justify subdelegation in principle (and he thought the principle satisfied in the case of the excise districts).

Put aside (1) whether Madison was right to concede the "necessity" of letting the President fix the excise collection districts and (2) whether fixing the districts was even an "important subject[]" for which serious subdelegation analysis was necessary or was instead a matter of "less interest." (The location of post roads was clearly among the "important subjects" in 1791; being on a post road was a huge economic boon, equivalent to a federal pork-barrel water project.) Focus just for the moment on the general principle that necessity, of some degree, might justify subdelegation, presumably on the theory that if it is strictly necessary to accomplish the stated tasks, the principal must have intended to allow sufficient subdelegation to allow effective completion of the tasks. If that is right - and Joseph Story certainly thought it was right - then one must ask one very large question in the context of the federal Constitution: What are the tasks with which We the People charged its agent Congress? One cannot judge whether subdelegation is necessary to accomplish a task without knowing what task is to be accomplished.

to which their authority was to extend, and their number, was very properly left with the Executive. In that instance, such a delegation was indispensably necessary; nor was it, in his opinion, less necessary in the multifarious arrangements of post offices”).

101 Id. at 238 (statement of Rep. Madison). 
Consider in this regard the Supreme Court's (spectacularly unsuccessful) attempt to rid the world of subdelegation challenges in Mistretta v. United States, ${ }^{102}$ in which the Court made it very clear that claims that Congress had granted too much discretion to executive agents would not be well received. ${ }^{103}$ The Court's rationale for the post-New Deal case law was refreshingly direct: "our jurisprudence has been driven by a practical understanding that in our increasingly complex society, replete with ever changing and more technical problems, Congress simply cannot do its job absent an ability to delegate power under broad general directives.”104 It is easy to roll one's eyes at this transparently political and sorry excuse for constitutional reasoning, but consider the awful possibility that the Court just might be at least partially right as a matter of original meaning.

What is Congress's “job,” according to the Court in Mistretta? The Court does not exactly say, though we know that whatever the Court thinks is Congress's “job” cannot be accomplished without the kind of subdelegation that pervades the modern administrative state. That is all we need to fill in the gap: The Court in Mistretta is assuming that Congress's "job" is to create, maintain, sustain, and empower the modern administrative state. If that is indeed Congress's constitutional "job," there is at least a credible argument that, as a practical matter, Congress "needs" to subdelegate authority to implement a regulatory structure of that magnitude. Yes, there are available to Congress procedural devices, such as fast-track approvals of legislation codifying agency action, that can increase its capacity to legislate, and those could go some distance towards reconciling a large role for the federal government with a strict rule against subdelegation. But

102488 U.S. 361 (1989).

103 Lawyers and lower courts did not get the message, either in Mistretta or in the numerous other unanimous or nearunanimous rejections of subdelegation challenges between 1989 and 2019. See GARY LAWSON, FEDERAL Administrative LAW 156-65 (8 ${ }^{\text {th }}$ ed. 2019).

104488 U.S. at 372. 
expecting Congress to vote on everything that shows up in the Code of Federal Regulations and (it is easy to overlook this aspect of the administrative state) on every significant matter of policy that shows up in an agency adjudication is simply not feasible. If Congress's "job” is indeed to micro-manage the entirety of American society, there is at least a serious argument that massive subdelegation can be justified by even a strict Madisonian understanding of necessity.

There are serious and intelligent thinkers who believe that this is indeed Congress's "job.” Think about how many people you know in this business who believe in constitutional welfare rights, who think that the Preamble means that America must adopt socialism because nothing else will "establish Justice," and so forth. If that is truly the right substantive account of American constitutionalism, then the subdelegation question takes a very different turn.

Of course, as a matter of the Constitution's actual communicative meaning rather than its conformance to a trendy political agenda, Congress obviously does not have constitutional power, much less constitutional responsibility, to run Leviathan. But this means that limited government is in fact a crucial premise in the argument for a subdelegation doctrine. It is important to that argument that Congress's “job” not involve such a massive overseeing of everybody's lives, fortunes, and sacred honors that subdelegation meets a strict requirement of necessity to effectuate those tasks. If one believes that Congress's "job" is to legislate in accordance with the limited set of tasks that it is given by the enumerations of legislative powers in the Constitution, there is no chance that a strict-necessity-based argument for subdelegation passes the laugh test. But that means that Justice Gorsuch is wrong to suggest that the scope of federal power and the subdelegation doctrine are unconnected. Arguments for limited government - or at least against unlimited government -- are essential to arguments against subdelegation. 
Thus, the interpretatively correct account of subdelegation probably does not provide all of the assurances that Justice Gorsuch wants to give to Justices who balance constitutional meaning against judicial restraint and end up with the latter more often than not. Congress does not have broad power to allow executive or judicial agents to "fill up the details." It can only do that with respect to matters of "less interest," so there is no way to avoid determining what matters are "important subjects" and matters are of "less interest" in each statutory scheme. Nor can one categorically state that subdelegation is unrelated to the overall size and scope of federal power. If one believes in the subdelegation doctrine, one has to believe, at least to some degree, in constitutionally limited government. In other words, one has to believe, at least to some degree, in the Constitution as it is written.

None of this means, of course, that a judge, as opposed to a scholar, must run the subdelegation doctrine to its ultimate conclusion. The law in the world, as opposed to the law in the academy, is full of circumstances in which principle gives way to practice. A major scholar has written a 500page book illustrating precisely this point. ${ }^{105}$

A perfectly sensible view, for example, would be to say:

(1) the subdelegation doctrine presupposes some conception of limited government, so it does not permit any and all arrangements that Congress would like to enact;

\footnotetext{
105 See LAwrence Lessig, Fidelity and Constraint: How the Supreme Court Has ReAd THE AmERican COnstitution (2019). For a trenchant critique of Professor Lessig's normative suggestions, see the book review by Amul R. Thapar \& Joe Masterman, Fidelity and Construction, 129 YALE L.J. 774 (2020). The review does not take serious issue with Professor Lessig’s descriptive claims.
} 
(2) the proper test for subdelegation is the agency-law test that would have been obvious to any private-law lawyer in 1788; but

(3) as a matter of precedent, laws that have been upheld or upon which significant institutional capital has been constructed will be grandfathered in, whether or not they are consistent with original meaning; but but

(4) that is far as things will be allowed to go, so new innovations or laws that are recent enough not to have given rise to significant expectation interests are fair game for serious judicial investigation and possible invalidation.

This set of propositions keeps faith with the original meaning of the Constitution by not allowing past distortions in practice to distort constitutional meaning, while recognizing the basic fact that constitutional meaning is not the only force driving constitutional adjudication.

To be clear: I am not endorsing this approach as an adjudicative theory. Adjudicative theory is a sub-species of moral and political theory, and I have nothing interesting or useful to contribute to the world as a moral or political theorist. I simply note that for a Justice who considers fidelity to original meaning an important part of adjudicative theory but thinks it must be bounded by some (relatively modest measure of) extra-constitutional considerations, this is a possible approach to take. Further the deponent saith not.

A full explication of the implications of this approach would require a book-length discussion of adjudicative theory, and that is not on the menu for the moment. For now, I want to make only two points.

First, focusing on the distinction between interpretation and adjudication requires one to keep clear two ideas that one should be keeping clear even without regard to the present problem: ascertaining constitutional meaning and engaging in constitutional decision-making. The former 
is an empirical, descriptive enterprise that seeks to answer the question: What is the objective communicative content of a particular expression or set of expressions? The second activity is a normative enterprise: How should real-world legal actors choose to deploy the instruments of governmental violence? It is possible to say that constitutional decision-making should be based solely on constitutional meaning, but it is also possible that say that the latter is relevant to the former but not necessarily decisive for it. ${ }^{106}$ If we assume that there are presently five Justices who think that constitutional meaning contributes more than trivially and rhetorically to constitutional decision-making, there may be some attraction to the idea that vested expectations ought not to be undone, however unconstitutional they may be, but that future expectations need to conform to constitutional meaning.

As a matter of interpretative theory, the key point to emphasize is that precedent is a device for guiding normative decision-making. It is not a device for ascertaining constitutional meaning. Past precedents do not "fix" or "liquidate" (to use the in-vogue Madisonian term ${ }^{107}$ ) the Constitution’s communicative meaning. They might, however, generate vested expectations, and if one treats those expectations as vested rights, then there is an adjudicative basis for leaving those vested rights untouched.

Second, private law, this time the law of property rather than the law of agency, provides an apt analogy. Consider the law of adverse possession. If someone adversely possesses an interest, it does not change the communicative meaning of the grant that created the interest. The

\footnotetext{
106 Larry Solum has defined the "contribution thesis" as the claim that "the content of constitutional law is constrained by the linguistic meaning of the constitutional text." Lawrence B. Solum, District of Columbia v. Heller and Originalism, 103 Nw. U.L. REV. 923, 954 (2009). The contribution thesis does not specify to what extent communicative meaning constrains decision-making. This article assumes that at least five Justices consider it at least a significant constraint.

107 See William Baude, Constitutional Liquidation, 71 STAN. L. REV. 1 (2019).
} 
grant, as a matter of communicative meaning, still conveyed the property to the previous possessor.

The law simply chooses to ignore the ordinary legal consequences of the grant. And the fact of adverse possession has no effect, communicative or legal, on the other interests in the grant. Adverse possession of the present interest has no effect on the future interests. Nor would an objectively faulty judgment allowing adverse possession of the present interest justify later objectively faulty judgments regarding the future interests. The meaning of the grant is one thing; its legal effect is another.

Justice Scalia recognized the aptness of the comparison. In Tyler Pipe Industries, Inc. v. Washington State Dep't of Revenue, ${ }^{108}$ Justice Scalia argued for limiting the application of the dormant commerce clause doctrine to cases of interstate discrimination. In resisting the Court's expansion of the doctrine in that case, Justice Scalia remarked: "It is astonishing that we should be expanding our beachhead in this impoverished territory [of the dormant commerce clause], rather than being satisfied with what we have already acquired by a sort of intellectual adverse possession." ${ }^{109}$ When courts choose precedent over constitutional meaning, they are allowing a past wrong to prevail over the formally valid title (with objective communicative meaning playing the role of title), at least partly because of the passage of time and the formation of expectations based on mere possession. Many of the arguments in favor of precedent - stability, reliance, costsavings, and so forth - are also arguments that can be made in favor of adverse possession. ${ }^{110}$ But precedent in this sense is a tool for decision-making. It is not a tool for interpretation of a text.

\footnotetext{
108483 U.S. 232 (1987).

109 Id. at 265 (Scalia, J., concurring in part and dissenting in part).

110 For a compendium of arguments in favor of adverse possession, see Jeffrey Evans Stake, The Uneasy Case for Adverse Possession, 89 GEO. L.J. 2419 (2001). To be clear: I am not endorsing the arguments for either precedent or adverse possession. I am simply pointing out their similarities.
} 
Rather, it is a reason for choosing to ignore the interpretation of a text. As Christopher Green has brilliantly put it:

Recognizing the distinction between when to interpret and how to interpret is the key to seeing why recognizing the power to adhere to a possibly-incorrect earlier decision does not entail recognizing a general power to revise the Constitution freely. Deciding that it is more important that some issues are more importantly settled than settled correctly does not alter the criterion for what answers are actually correct. The Constitution still means what it means, and interpreters subject to an adverse-possession rule need neither surrender their convictions about its meaning through the equivalent of an intellectual lobotomy, nor believe that interpreters are free to shift and morph the meaning of the Constitution without any constraint. Precisely because it is part of constitutional construction, and not constitutional interpretation, an adverse-possession model for adherence to incorrectly-decided precedent would merely limit the power of present interpreters to give effect to their interpretations; it would not affect their interpretations as such. ${ }^{111}$

If one recognizes precedent as akin to adverse possession, it will become clear that allowing the precedent/possession to prevail over the meaning/title in one instance does not affect the validity of surrounding meanings/titles. The effects of adverse possession are confined to the specific possessory interest that has been adversely possessed. There are good reasons to treat precedents the same way, allowing previous interpretative errors to stand when reliance or other

111 Christopher R. Green, Constitutional Theory and the Activismometer: How to Think About Indeterminacy, Restraint, Vagueness, Executive Review, and Precedent, 54 SANTA Clara L. ReV. 403 (2014). 
interests strongly counsel it but not using that mistake as a justification for future mistakes. Hence:

"this far but no further."112

There is obviously much more that one could say about how to frame an argument along these lines. That is not my wheelhouse; I am neither an adjudicative theorist nor a litigator. But for those who value both constitutional meaning and settled practice, “this far but no further” has promise as a limiting principle, if a limiting principle one seeks.

112 For a critique of this idea, see Daniel A. Farber, The Rule of Law and the Law of Precedents, 90 MiNN. L. REV. 1173, 1182-83 (2006):

Unlike the doctrine of adverse possession in property law, which is peripheral to the system of property ownership, stare decisis in constitutional law changes the nature of the enterprise. Bedrock precedents cannot be quarantined; instead, they inevitably affect the system of constitutional law as a whole.

The originalist impulse regarding these bedrock but allegedly "wrong” precedents is to say "this far, but not an inch farther." Under this view, the court should not overrule key precedents, but it should always return to first principles in considering new issues. But this is an untenable stance in a legal system that seeks some form of coherence.

If one regards coherence with previous decisions, as opposed to coherence with constitutional meaning, as the paramount value, there is something to this argument. But it is obviously circular. And it begs important questions about what a precedent contains and what would constitute an expansion of it. 